\title{
ANALISIS MAKHLUK SUPERIOR (NAGA) DALAM LEGENDA DANAU KEMBAR (KAJIAN SEMIOTIKA ROLAND BARTHES; DUA PERTANDAAN JADI MITOS)
}

\author{
Prina Yelly \\ Dosen STKIP Budidaya Binjai \\ prinayelly4@gmail.com
}

\begin{abstract}
ABSTRAK
Kajian Semiotika Roland Barthes; dua pertandaan jadi mitos, dikaji dalam analisis legenda Danau Kembar. Legenda Danau Kembar menceritakan tentang pertarungan antara naga dan kakek (Inyiak). Metode yang digunakan dalam kajian ini adalah metode deskriptif analisis. Objek yang dikaji adalah analisis legenda Danau Kembar semiotika Roland Barthes, yaitu berupa makna denotasi, makna konotasi, dan mitos.
\end{abstract}

Kata Kunci: Naga, Danau Kembar, semiotika Roland Barthes

\section{PENDAHULUAN}

Sumatera Barat adalah sebuah provinsi di Indonesia yang terletak di Pulau Sumatera dengan ibu kota yang bernama Padang. Sumatera Barat ini memiliki beberapa objek wisata, salah satunya wisata danau air tawar, seperti Danau Singkarak, Danau Maninjai, dan Danau Atas serta Danau Bawah atau yang lebih dikenal dengan sebutan Danau Kembar.

Dari beberapa danau tersebut, penulis tertarik untuk mengkaji Danau Kembar sebagai objek kajian karena danau ini memiliki cerita rakyat (legenda). Legenda adalah cerita prosa rakyat yang dianggap oleh empunya cerita sebagai suatu

kejadian yang sungguh-sungguh pernah terjadi. Legenda sering dipandang sebagai "sejarah" kolektif (folk history), karena "sejarah" tidak tertulis, maka mengalami distorsi sehingga ceritanya sering jauh berbeda dengan kisah aslinya (Danandjaja, 2007).

Legenda Danau Kembar menceritakan tentang pertarungan antara naga dan kakek yang disebut juga dengan
Inyiak. Legenda itu sudah dijadikan sebuah Antologi Cerita Rakyat Sumatera Barat (Legenda Danau Kembar) oleh Pinto Anugrah. Oleh karena itu, penulis membahasnya dengan kajian Semiotik. Semiotik yang digunakan adalah Semiotika Roland Barthes.

Semiotika berasal dari bahasa Inggris semiotic, sedangkan dalam bahasa Yunani semeion, yaitu tanda, atau teori tanda-tanda (Bagus, 2000:985). Mengkaji tanda-tanda untuk menemukan makna-makna yang ada dibaliknya. Menurut Saussure semiotika atau semiologi merupakan ilmu yang mengkaji tanda-tanda dalam kehidupan sosial (Saussure, 1988:82).

Semiotika Roland Barthes tentang mitos. Roland Barthes merupakan sosok penting dalam perkembangan ilmu semiotika. Barthes dikenal sebagai tokoh penerus dari tokoh strukturalis Ferdinad De Saussure dalam bidang semiotika. Barthes lahir 12 November 1915 di Cherboug, Normandia, Perancis. Karya-karya yang dihasilkan oleh Barthes di antaranya, Elementary of Semiology, S/Z, Mythologies, Camera Lucida 
dan beberapa karya esai lain, seperti the death of author. Barthes Meninggal 26 Maret 1980 (Barthes, 2010:13).

Semiologi (atau semiotika) Roland Barthes mengacu pada Saussure dengan menyelidiki hubungan antara penanda dan petanda pada sebuah tanda. Hubungan penanda dan petanda ini bukanlah kesamaan (equality), tetapi ekuivalen. Bukannya yang satu kemudian membawa pada yang lain, tetapi korelasilah yang menyatukan keduanya (Barthes, 1972)

Barthes juga melihat aspek lain dari penandaan, yaitu "mitos" yang menandai suatu masyarakat. Mitos menurut Barthes terletak pada tingkat kedua penandaan, jadi setelah terbentuk sistem tanda-penandapetanda, tanda tersebut akan menjadi penanda baru yang kemudian memiliki petanda kedua dan membentuk tanda baru (Barther,

1972).

\section{Dua Tatanan Pertandaan Roland Barthes}

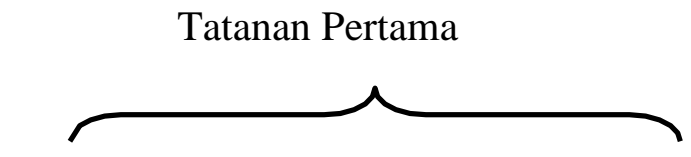

Realitas

Dalam pandangan Barthes, pembahasan tentang mitos tidak lepas dari pengertian ideologi. Bahkan, analisis
Tatanan Kedua

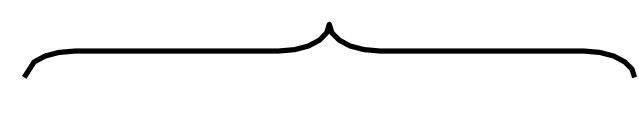

Kultur

tentang mitos dapat berarti kritik atas sebuah ideologi di dalam masyarakat.

\section{Bahasa/Denotasi \\ MITOS/Kanotasi}

Mitos menurut Barthes dalam bukunya yang berjudul Mythologies, mitos adalah sebuah sistem komunikasi, bahwa mitos adalah sebuah pesan. Mitos adalah mode penandaan, sebuah wujud. Barthes $p$ erc aya bahwa s e mua benda bisa menjadi mitos. Asalkan benda tersebut sudah mengandung pesan, maka benda itu menjadi mitos. Menurut Barthes juga sifat lain dari mitos adalah bahwa mitos tidak d ite ntukan oleh materinya, me lainkan oleh yang disampaikan (Zaimar, 2008:58).

\begin{tabular}{|r|r|r|}
\hline 1. Penanda & 2. Petanda & \\
\hline $\begin{array}{r}\text { 3. Tanda } \\
\text { I PENANDA }\end{array}$ & II PETANDA \\
\hline \multicolumn{2}{|r}{ III TANDA } \\
\hline
\end{tabular}

Mitologi adalah bagian dari semiologi, yaitu ilmu yang luas tentang tanda dan bentuk. Mitologi dan semiologi, kedua-duanya berurusan dengan nilai yang tidak hanya puas dengan fakta. Fakta merupakan tanda yang digunakan untuk mendefinikan dan menjelajahi hal lainnya. Menurut Barthes (1972:113) dalam mitos ditemukan pola tiga dimensi penanda, petanda, dan tanda. Mitos adalah sebuah sistem khusus yang dibangun dari rantai semiologis yang sudah ada sebelumnya. Proses signifikasi ini disebutnya denotasi dan konotasi (Kris, 
2004: 63-65). Makna denotasi bersifat langsung, artinya makna khusus yang terdapat dalam suatu tanda atau gambaran dari sebuah petanda. Sedang, makna konotasi akan dihubungkan dengan kebudayaan yang tersirat dalam pembungkusnya, yaitu makna yang terkandung di dalamnya (berger, 2005:55).

\section{METODE}

Metode yang digunakan dalam kajian ini adalah metode deskriptif analisis. Metode tersebut merupakan suatu cara untuk pemecahan masalah dengan cara menggambarkan suatu objek. Objek yang dikaji adalah analisis legenda Danau Kermbar. Legenda tersebut diungkapkan melalui semiotika Roland Barthes, yaitu berupa makna denotasi, makna konotasi, dan mitos.

\section{HASIL DAN PEMBAHASAN}

\section{Asal Usul Legenda Danau Kembar}

Legenda Danau Kembar menceritakan tentang seorang laki-laki tua (kakek) yang bernama Inyik Gadang Bahan. Dia disebut dengan nama Inyik Gadang Bahan karena kapak atau kampaknya berukuran besar. Suatu ketika, Inyik Gadang Bahan pergi ke hutan untuk mencari kayu bakar, dia berjumpa dengan seorang nenek. Kemudian, nenek tersebut menasehatinya untuk berhati-hati di sana karena ada bahaya.

Saat di hutan, Inyik Gadang Bahan melihat pohon-pohon yang sudah patah dan tumbang. Dia jadi teringat nasehat nenek untuk kembali ke perkampungan. Ketika, Inyik Gadang Bahan melangkah menuju ke perkampungan ternyata dia dihadang oleh seekor naga yang sangat besar.

Naga merasa terusik oleh kedatangan Inyik Gadang Bahan. Dia pun menyerang Inyik tersebut dengan semburan api. Pertempuran tersebut akhir melukai naga. Naga pun mengeluarkan darah pada bagian kepala dan ekornya. Kemudian, darah naga berubah menjadi danau. Danau itu yang disebut dengan Danau Kembar (Danau Atas dan Danau Bawah). Danau Atas adalah kepala naga dan Danau Bawah adalah ekor naga, sedangkan tempat pertarungannya dinamakan Lembah Gumanti. Padang pengembalannya disebut dengan Alahan Panjang.

\section{ANALISIS LEGENDA DANAU KEMBAR (KAJIAN SEMIOTIKA ROLAND BARTHES; DUA PERTANDAAN JADI MITOS)}

Semiotika Roland Barthes (1915-
1980) mengembangkan dua tingkatan
pertandaan, yaitu tingkat denotasi dan
konotasi. Referensi terhadap penanda yang
ditandai sering disebut sebagai signifikasi
tataran pertama (first order of signification),
yaitu referensi denotasi, sedangkan konotasi
disebut sebagai sistem penanda tataran kedua
(second order signifying system).

\section{a. Denotasi}

Denotasi adalah tingkat pertandaan yang menjelaskan hubungan antara signifier dan signified, atau antara tanda dan rujukannya pada realitas, yang menghasilkan makna yang eksplisit, langsung, dan pasti. Sedangkan konotasi adalah tingkat pertandaan yang mejelaskan hubungan antara signifier dan signified, yang di dalamnya 
beroperasi makna yang tidak eksplisit, tidak langsung, dan tidak pasti (artinya terbuka bagi segala kemungkinan). Barthes menciptakan peta tentang bagaimana tanda bekerja (Cobley \& Jansz, 1999 dalam Sobur, 2009: 69).

Adapun makna denotasi dalam pembahasan ini yang menjadi tanda adalah kata naga. Naga dalam KBBI, yakni ular besar (dalam cerita dan dalam kata majemuk), seperti berapi, bura, gentala, umbang; atau ular besar (menurut kepercayaan) penunggu mata angin (ada yang berpindah tiap hari, ada yang tiap tahun, seperti hari, tahun) (2008:948).

\section{b. Konotasi}

Konotasi merupakan penanda yang secara bersamaan merupakan tanda denotasi yang terdiri dari penanda dan petanda. Tanda denotatif terdiri atas penanda dan petanda. Namun pada saat bersamaan, tanda denotatif adalah juga penanda konotatif. Menurut Vera (2014), bahwa belajar dari pandangan Saussure, Barthes meyakini bahwa hubungan antara penanda dan petanda tidak terbentuk secara alamiah, melainkan terjadi melalui kesepakatan konvensi sosial (arbiter). Penyempurnaan yang dilakukan Barthes dalam mengembangkan sistem penandaan pada tingkat konotatif, berangkat dari penandaan Saussure yang ditekankan pada tataran denotatif. Selain mengembangkannya pada tatanan konotatif, Barthes juga melihat aspek lain dari penandaan, yaitu "mitos" yang menandai suatu masyarakat.

Adapun kata konotasi yang akan dibahas adalah kata naga. Naga merupakan makhluk yang universal dan simbolik yang dapat ditemui dalam kebudayaan di dunia (Cirlot, 1971:88). Selain itu, terdapat juga perbedaan pandangan yang signifikan antara kebudayaan barat dan timur terhadap naga.

Dalam kebudayaan barat, naga diidentikkan dengan simbol kejahatan, cenderung merusak, dan dianggap sebagai musuh yang harus dihancurkan. Beberapa mitologi Eropa menjelaskan, bahwa seseorang yang dapat mengalahkan naga disebut sebagai pahlawan (Cirlot, 1971:88).

Adapun makna konotasi dalam Analisis Legenda Danau Kembar (Kajian Semiotika Roland Barthes; Dua Pertandaan Jadi Mitos) adalah kata naga. Naga merupakan sosok yang memiliki karakter jahat dan simbol dari kerakusan dan ketamakan.

\section{c. Mitos}

Mitos adalah sebuah cerita di mana suatu kebudayaan menjelaskan atau memahami beberapa aspek dari realitas atau alam. Mitos primitif adalah mengenai hidup dan mati, manusia dan Tuhan, baik dan buruk. Sementara mitos terkini adalah soal maskulinitas dan feminitas, tentang keluarga, tentang kesuksesan tentang ilmu pengetahuan dan sebagainya. Mitos, bagi Barthes, sebuah budaya cara berpikir tentang sesuatu, cara mengonseptualisasi atau memahami hal tersebut. Barthes melihat mitos sebagai mata rantai dari konsep-konsep yang berelasi (Fiske, 2014: 143-144).

Mitos dalam pandangan Barthes, seperti di jelaskan Vera (2014), merupakan bahasa. Dari pandangan tersebut mitos berarti suatu sistem komunikasi dan sebuah pesan. Mitos dalam metode semiotika Barthes tersebut merupakan pengembangan dari konotasi. Singkatnya, konotasi yang sudah terbentuk lama dan menjadi pandangan masyarakat merupakan mitos. Bagi Barthes 
mitos adalah sistem semiologis berupa sistem tanda-tanda yang dimaknai manusia.

Mitos yang terdapat dalam legenda danau ini adalah naga mengeluarkan darah pada bagian kepala dan ekornya. Kemudian, darah naga berubah menjadi dua danau, yakni Danau Atas dan Danau Bawah. Danau Atas adalah kepala naga dan Danau Bawah adalah ekor naga. Jadi, sampai saat ini masyarakat Minangkabau terutama yang berada di sekitar Danau Kembar percaya bahwa itu adalah asal usul danau kembar.

\section{SIMPULAN}

Dari hasil Analisis Legenda Danau Kembar (Kajian Semiotika Roland Barthes; Dua Pertandaan Jadi Mitos), maka dapat disimpulkan bahwa terdapat makna denotasi kata naga sebagai penanda dan konotasi dari kata naga tersebut sebagai tanda. Tanda itu berupa mahluk yang jahat, tamak, dan rakus, sedangkan mitosnya berupa danau berasal dari darah naga. Darah yang keluar dari kepala dan ekor. kepala naga menjadi danau atas, sedangkan ekor naga menjadi Danau Bawah.

\section{DAFTAR PUSTAKA}

Bagus, Lorens. 2000. Kamus Filsafat. Jakarta: Gramedia Pustaka Utama.

Barthes, Roland. 2010. Memebedah MitosMitos Budaya Massa. Yogyakarta; Jalasutra.

Barthes, Roland. 1972. Mythologies. New York: The Noonday Press
Berger, Arthur Asa. 2005. Tanda-tanda dalam Kebudayaan Komtemporer: Suatu Pengantar Semiotika, Yogyakarta: Tiara Wacana.

Budiman, Kris. 2004. Jejaring Tanda-tanda: Strukturalisme dan Semiotika dalam Kritik Kebudayaan, Magelang: Indonesiatera.

Cirlot, J. E. 1971. A Dictionary of Symbols. Taylor \& Francis e-Library

Hoed, Benny H. 2003. "Strukturalisme de Saussure di Prancis dan Perkembangann ya," dalam Prancis dan Kita, Irzanti Sutanto dan Ari Anggari Harapan (peny). Jakarta: Wedatama Widya Sastra

Sobur, Alex. 2009. SemiotikaKomunikasi. Bandung: PT. Remaja Rosdakarya

Saussure, Ferdinand De. 1988. Pengantar Linguistik Umum. Diterjemahkan; Rahayu S. Hidayat. Yogyakarta; Universitas Gajah Mada Press.

Zaimar, Okke K. S. 2008 . Semiotik dan Penerapannya dalam Karya Sastra . Jakarta: Pusat Bahasa. 